\title{
旅行者発信情報を収集可能な観光マネジメント支援システムの開発 DEVELOPMENT OF TOURISM MANAGEMENT SUPPORTING SYSTEM WHICH CAN COLLECT TOURIST'S ASPECTS
}

\author{
福田知弘*, 吉川泰代**, 矢吹信 喜*** \\ Tomohiro FUKUDA, Yasuyo YOSHIKAWA and Nobuyoshi YABUKI
}

\begin{abstract}
It can be said that improving tourism facilities will be indispensable for the economy of our country in the future. To improve tourism facilities, tourism information evaluated by tourists should be collected and transformed into useful knowledge, and then this knowledge should be used for the planning and the improvement of tour routes and the infrastructure of sightseeing areas. Therefore, this research describes a tourism management supporting system. Management system was composed of collection system and sharing system. The collection system was used to identify tourists' needs accurately, effectively and widely by using a CPCG (Cell-Phone with Camera and GPS) and by developing an Information Management Server. Sharing system was to transform the collected information to 4 kind of useful knowledge; confirmation, discovery, disappointment and hate, and to display them. To verify the proposed methods, the author carried out a social experiment. The experiment showed that the proposed system was effective.
\end{abstract}

Keywords : tourism management, supporting system, tourist's aspect, GPS portable telephone, cloud computing 観光マネジメント，支援システム，旅行者発信情報，GPS カメラ付き携帯電話，クラウドコンピューティング

1. はじめに

\section{1 旅行者発信情報の収集状況}

我が国では，観光を 21 世紀の国づくりの柱のひとつとして，観 光立国の実現を目指している. 観光振興は, 交流人口がもたら寸観 光消費による経済波及効果はもとより，交流を契機に地域の自然， 歴史，文化伝統を見直す観点からも，地域の活性化を図るための重 要な施策となっている. そのため観光振興を総合的かつ計画的に推 進するために，施策の推進状況の点検と計画を見直す観光マネジメ ントが重要な事項の一つとして位置づけられている ${ }^{1)}$.

観光マネジメントを的確に行うためには，観光旅行者（以下，旅 行者）から発信される情報（以下，旅行者発信情報）を収集し，国・ 地方公共団体 ・ 観光事業者・住民等の関係者で共有し, 計画の点検 や見直しをするアクションプロセスで活用されることが必要である. ここで，旅行者発信情報とは，旅行者が新たに発見した地域資源や ッアーガイドに対する感想，不満などの観光ツアーの内容に関する 情報や, 案内標識が混在・不足している, 歩道が整備されておらず 危険である, 違法駐輪や落書きが多いなどの観光ルート上に存在す る情報が含まれる．

このような旅行者発信情報の収集・共有は，十分になされている 状況とは言い難い ${ }^{2)}$. 例えば, 観光ツアーの評価は, ッアー終了後 に紙媒体のアンケートなどで実施されているが，ツアー終了後の調
查では, 印象の変化や風化の問題が指摘されており, 現場での評価 を的確に得るには不十分である。現状は旅行者の評価や現場の最新 情報を的確に収集・共有する手段がないともいえ，結果として現場 からの的確な情報がないままにアクションプロセスが実施されてし まい，事業者と旅行者との間にずれが生じることとなる.

\subsection{ICT の発展と応用の広がり}

旅行者発信情報を的確に収集する方法として，情報通信技術 (Information and Communication Technology，以下 ICT）の利用が考 えられる。低廉で高速なネットワーク整備が進み,「いつでも, ど こでも，誰でも」利用できる「ユビキタスネット社会」の到来は現 実になりつつある. 平成 22 年 1 月現在, インターネットの人口普及 率は $78.0 \%$ となっている. 加えて, 情報通信機器の利用状況は年々 上昇傾向にあり，携帯電話及び PC の個人利用率は，携帯電話 （74.8\%）が PC（66.2\%）を上回っている ${ }^{3)}$ 。このように ICT 基盤 の整備と利用が進む中，ICT を応用した調査方法の開発，情報提供 方法の開発，情報収集・管理手法の開発などが社会基盤分野をはじ めとして検討されている ${ }^{4) 5(6) 7) . ~}$

\section{3 既往研究と本研究の位置づけ}

1.1 節で述べた, 旅行者発信情報の収集・共有の方法を実現する ためには，まず，旅行者発信情報をその場で収集するシステム（以 下，収集システム）が必要となる。ささに，旅行者がどのような意

本論文は, 平成22年度日本建築学会近畿支部研究報告集に挄いて発表した論文 ${ }^{23)}$ に加筆・修正したものである。

* 大阪大学大学院工学研究科環境・エネルギー工学専攻Ａssoc. Prof., Division of Sustainable Energy and Environmental Engineering, Graduate 准教授・博士 (工学)

** パシフィックコンサルタンツ(株) 工修

*** 大阪大学大学院工学研究科環境・エネルギー工学専攻 教授・Ph. D.

School of Engineering, Osaka University, Dr. Eng.

Pacific Consultants Co., Ltd., M. Eng.

Prof., Division of Sustainable Energy and Environmental Engineering, Graduate School of

Engineering, Osaka University, Ph. D. 
図によりその情報を発信したのかを把握した上で関係者が共有する システム（以下，共有システム）を構築できれば, 収集された情報 はアクションプロセスでの資料となりうる. この, 実現すべき要件 を汎用性の高い ICT を用いて構築することにより, 不特定多数の旅 行者や観光事業者にとって実用性が高くなると考えられる. 本研究 では、この要件を満たすシステムを観光マネジメント支援システム と定義する。以下に, 既往研究について整理する.

収集システムに関する既往研究として, 近年, GPS や IC タグな どの位置推定に関する技術を用いて歩行者や旅行者のルート案内や 回遊行動に関寸る研究 ${ }^{819)}$ 10) 11) 12) が行われている.これらは, 位置 推定情報を用いて歩行者や旅行者の行動を取得・分析している点で 本研究と類似寸る点が見られるが，旅行者の評価や要望をリアルタ イムに収集することができない点で異なる.また, 被験者が現場に 訪れて評価した情報を収集する手法に関する研究も存在するが 13) 14)，情報の収集や処理のために特定の PDA やアプリケーションを 用いている点で, 汎用性に劣るという課題が残る。 また, 景観調査 に用いた研究 15)では, 汎用的な GPS カメラ付き携帯電話（以下, GPS 携帯端末）を用いた汎用性の高いシステムを構築し, 景観形成 の資料を導き出しているが, 蓄積された情報の提示・共有方法につ いて報告されていない.

共有システムに関する既往研究として，市民が対象地域内を歩き ながら撮影した写真を, 歩いたルート上に投稿される共有システム の構築が散見されるが 16) 17), 投稿された情報に対する意図を分類し た上での提示方法についての検討はなされていない.

最後に, 本研究が目指すような, 収集システムと共有システムと を包括的に扱う研究について述べる. 筆頭著者らの研究 18)では, GPS 携帯端末を用い，被験者から画像と付加情報を収集し，2D • $3 \mathrm{D}$ 空間に情報を配置しているものの, 収集した情報に対する考察 やシステムの評価を述べるには至っていない，また，パークマネジ メントに用いた研究 14)では, 対象分野及び蓄積された情報の共有方 法が本研究とは異なる.

以上より, 本研究が対象とするような旅行者発信情報を扱った観 光マネジメント支援システムの報告は見当たらないこと, また, 類 似の分野においても汎用性の高いシステムを構築してリアルタイム に現場評価を行い, 旅行者発信情報を収集するシステムと, 大量に 蓄積される旅行者発信情報を旅行者の評価に基づいて分類・提示す るシステムを包括的に提示した研究は見られない.

\section{4 研究の目的}

そこで本研究では, 汎用性の高いハードウェア, ソフトウェアを 用いて, 観光マネジメント支援システムを構築し, その有効性を検 証することを目的とする. 本システムは, 収集システムと共有シス テムで構成される，収集システムは，旅行者のリアルタイムな現場 評価を収集するシステムである，共有システムは，大量に蓄積され る旅行者発信情報を旅行者の評価内容に応じて分類し, 関係者が共 有できるシステムである.

\section{2. 旅行者発信情報の 4 領域分類}

本研究では, 風土工学の「四空分析」19）を参考に, 旅行者発信情 報を，4 つの領域に分類する. 4 つの領域の作成方法は，横軸を旅 行者にとって既知の領域と未知の領域に分け, 縦軸を旅行者の評価

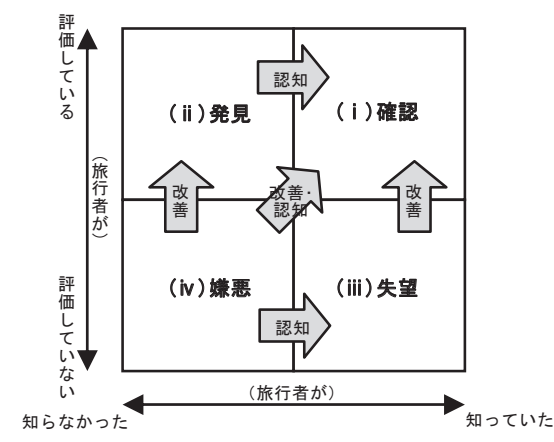

図 1 旅行者発信情報の 4 領域分類とアクションプロセス

が高い領域と評価が低い領域に分ける。これら 2 軸の交差により得 られる 4 つの領域をそれぞれ，（i ）確認，（ii）発見，（iii）失望， （iv）嫌悪と定義する.

（i 確認の領域は, 旅行者が既に知っており, 評価も高いため, 地域一の愛着の創出や再来訪の促進につながると考えられる. 今後 も地域の ‘顔” として, 観光ツアーやプロモーション活動等に積極 的に活用していくことが望ましい. (ii) 発見の領域は, 旅行者が元々 知らなかったが，評価が高い領域である。すなわち，旅行者にとっ ての新たな発見であると考えられる，今後，旅行者への認知度を高 めてゆくことで, 地域の新たな個性や魅力となりうる可能性がある.

（iii）失望の領域は，旅行者が元々知っていたのにも関わらず，評 価の低い領域である。すなわち，旅行者は訪問前には期待していた ものの, 訪問後, 失望したと考えられる.この領域は, 早急に改善 してゆくことが求められる. (iv) 嫌悪の領域は, 旅行者が元々知ら ず，かつ，評価も低い領域であり，改善点として認識しにくい領域 である．改善を検討していく必要がある，なお，（iv）嫌悪の領域は 未知の領域ともいえ，改善して認知度を高めれば，地域の個性・魅 力となる可能性も十分にある.

以上のように，旅行者発信情報を 4 つの領域にリアルタイムに収 集した後アアクションプロセスを検討する．（i）確認が最も好まし い状態であるとすると，（ii）発見は，認知度を高めることで（i ） 確認の領域へ,（iii）失望は, 改善することで（i ）確認の領域へ,

（iv）嫌悪は, 改善し, 認知度を高めることで,（i 確認の領域一 近づけるようにする. 図 1 に旅行者発信情報の領域分類とアクショ ンプロセスを示す.

\section{3. 収集システムの開発}

収集システムは，情報投稿者（旅行者など）が GPS 携帯端末を用 いて，画像情報・位置情報・評価情報を含む旅行者発信情報をリア ルタイムに管理サーバに投稿することが可能であり，投稿された情 報は管理サーバに蓄積される。

システムは，特殊な機器を用いず，個人レベルで広く普及してい る機器やソフトウェアを基に構築することで, 汎用性の高いシステ ムとする，これにより，旅行者がシステム操作の習得を容易にする こと，観光マネジメントの関係者がシステムを利用しやすくするこ とが可能となる.

\section{1 システムの構成}

収集システムは，GPS 携帯端末と，CGI プログラムおよびデータ 


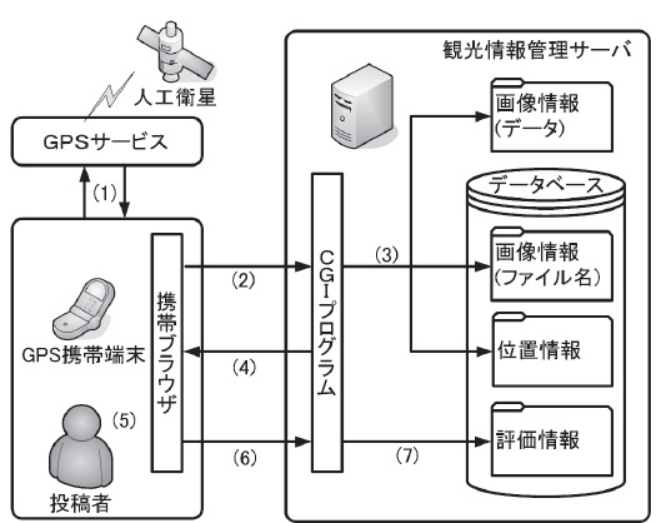

図 2 收集システムの構成図

ベースを含む管理サーバによって構成される. 開発言語には PHP （Ver.5.2.10）を利用し，データベースソフトウェアには高速性・安 全性・汎用性に優れた MySQL（Ver.5.1）を利用した。構成図を図 2 に示す.また，収集システムで開発した機能を以下に示す.

（1）画像情報の抽出・登録機能

管理サーバに投稿されたメールより,画像情報を自動的に抽出し， サーバ内部に格納する機能である。

画像情報の抽出・登録方法は，まず，受信したメールのヘッダよ り, CGI プログラムを用いて, from (差出人), body (本文) の image (添付画像) および filename（ファイル名）を抽出する. 次に, 抽 出した filename（ファイル名）を，取得した現在時刻を用いて一意 的なファイル名に変換した上でデータベースに登録する. 次に, サ 一バ内部のネットワーク公開フオルダに, image（添付画像）を格納 する. これにより, サーバ内部に蓄積される画像情報を, 共有シス テム開発後にWEB 上で誰でも閲覧することが可能となる.

（2）位置情報の抽出・登録機能

位置情報が付加された画像情報から, 位置情報を抽出し, データ ベースに登録する機能である.

位置情報は，画像ファイル中に, Exif ${ }^{20)}$ (Exchangeable image file format）形式で存在している。この Exif 形式の位置情報を, PHPの exif_read_data関数を用いて, image (添付画像) から, filename（フ アイル名), make (携帯端末製造元), model (携帯端末モデル), latitude (緯度), longitude (経度) を抽出し, auto_increment 関数を用いて 自動生成させた id (id 番号) と共に, データベースに登録する.こ こで, Exif 形式の latitude と longitude は dms 単位で表示されている が, 共有システムで Google Map サービスを利用することを考慮し, degree 単位に変換して登録する（図 3 (左) ).

(3) メール自動返信機能

管理サーバがメールを受信すると，評価フォームへアクセス寸る ための URL と投稿した画像情報が添付されているメールを自動返 信する機能である.

メール自動返信プログラムでは，受信したメールのヘッダより CGI プログラムを用いて抽出した from（差出人）を，送信するメー ルのヘッダの to（宛先）に設定する. また投稿者が評価対象物に関 する記憶を想起することを支援するため, 抽出した body（本文）の image（添付画像）を, PHP の Mail_mime ライブラリを用いて, 送 信するメールの本文に埋め込む。 これにより，自動返信されたメー

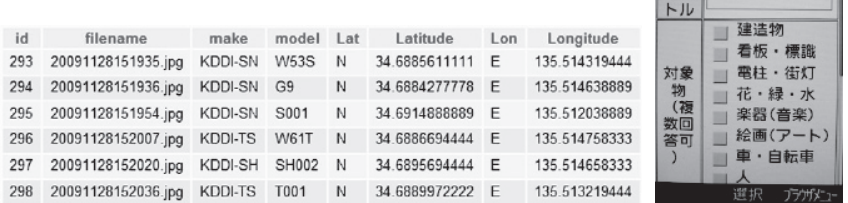

図 3 位置情報の DB 登録（左）と評価フォーム画面（右）

ルの本文に，投稿者が撮影した画像情報を添付される．

（4）フォーム表示機能

投稿者が受信フォルダ内部の受信メールを開くと，評価フォーム と画像情報が添付されたメール本文が表示される.このURLにアク セス寸ると CGI プログラムで作成された評価フォームが取得できる。

評価フォームのアンケート項目は, 操作性の観点から必要最小限 とする. 本研究では, 性別, タイトル, 対象物, 認知度, 評価, コ メントの 6 項目とした. 画面例を図 3 (右) に示寸. タイトルとコ メントはテキストフォームで構成され, 被験者である旅行者の自由 記述方式とする．性別はラジオボタンで構成され, 男女いずれかの 選択式とする. 対象物はチェックボックスで構成され,「建造物」,

「看板・案内」などのうち, 該当するものを複数回答可の選択式と する. 認知度, 評価はセレクトボックスで構成される. 選択項目は, 認知度（知らない，ほとんど知らない，どちらでもない，少し知っ ている, 知っている), 評価 (魅力的でない, あまり魅力的でない, どちらでもない, まあ鬼力的だ，魅力的だ）の選択式とする. 認知 度と評価に関する選択内容と 2 章で示した分類方法との関係に関し ては，5.1節で述べる。

（5）評価情報登録機能

投稿者が評価フォームの設問に回答し，確認画面にて内容を確認 した後, サーバ内部の CGI プログラムによって, 評価情報をデータ ベースに登録する機能である。

CGI プログラムが評価情報をデータベースに登録する際，POST 送信で情報をサーバに伝送する。この時 PEAR の DB 関数を用いる が，チェックボックスによる設問では，複数回答された項目を登録 する必要がある。そこで，PHPの implode 関数を用いて，選択され た配列の要素を文字列により連結させた上で, データベースに登録 する，さらに，先に登録した画像情報および位置情報のデータを自 動的に対応させるため, (2) 位置情報の抽出・登録の際に生成した id を, mysql_insert_id 関数により取得し, 評価フォームに GET で伝 送する.

\section{2 システム利用の流れ}

投稿者は地域の魅力ポイントや改善ポイントを発見し, GPS 携帯 端末で写真を撮影する. 次に撮影画像のサブメニューより「GPS 情 報を付加」を選択し, GPS サービスを利用して現在位置を取得する.

(図 2(1)). 次に投稿者が, 位置情報を付加した画像情報を添付し, 無題，本文なしのメールを管理サーバに送信すると（図 2 (2)), サ 一バ内部の CGI プログラムが，サーバ内部の特定のフォルダに画像 情報（データ）を格納する。同時に，データベースに画像情報のフ アイル名および位置情報を格納する（図 2 (3) ) 。画像情報と位置情 報をデータベースに格納した後, CGI プログラムが投稿者の GPS 携 
帯端末にメールを自動返信する（図 2 (4)) 。自動返信されたメール の本文には, 評価フォームへアクセス寸るための URL と投稿された 画像情報が添付されている. 投稿者は, インターネットを通じて URL にアクセスし，評価フォームを取得する（図 2（5））。最後に， 評価フォームを取得後, フォーム内の設問項目に回答し, 管理サー バに送信されると（図 2 (6)), CGI プログラムが, サーバ内部のデ ータベースに評価情報を登録する（図 2 (7)).

\section{4. 収集システムの検証}

開発した収集システムを検証するため，実証実験を実施した。検 証項目は, 収集されるデータの精度, 従来型手法との比較, システ ムのユーザビリティ評価である.

\section{1 実験方法}

実証実験は大阪市にて平成 21 年 11 月 21 日と 28 日に計 4 回, 滋 賀県近江八幡市にて平成 21 年 11 月 24 日の計 1 回の全 5 回実施し た。全 5 回とも，天候は晴れであった（図 4).

被験者は, 実験の主旨と GPS 携帯端末の使用方法を理解した後, GPS 携帯端末を持ちながら 2 時間程度のガイド付き観光ツアーを体 験し, 地域の魅力ポイントや改善ポイント（以下, 評価対象）の画 像を撮影し，画像情報と位置情報を管理サーバに送信した。実験ツ ア一後, 従来型手法と比較するため各被験者に紙の地図を配布し, 被験者が記憶に残っている評価対象の位置や評価コメントを記入し た. 地図への記入が終わると, GPS 携帯端末に自動返信された受信 メールを開き,それぞれの評価対象に対して評価フォームに回答し, 管理サーバに送信した。最後に，システムのユーザビリティに関す るアンケート調查を実施した。

被験者は男性が 11 名 $(29.7 \%)$, 女性 26 名（70.3\%）の計 37 名 であった．また，年齢構成は， 20 代が 19 名（51.4\%）と最も多く, 次いで 40 代が 8 名 $(21.6 \%), 30$ 代が 7 名 $(18.9 \%), 50$ 代が 3 名 (8.1\%)であった. 10 代および 60 代以上の被験者は 0 名であった. また, 被験者が普段良く使う携帯電話の機能を実験時に調查し, 各機能の使用状況に応じて, 3 種類のユーザ特性を設定した. 寸な わち, メール機能に加えてカメラ機能か web 機能の少なくともいず れかを使用しているユーザをパワーユーザ (14 名, 37.8\%), メール 機能は使用するがカメラ機能と web 機能は使用していないユーザを メールユーザ (20 名, 54.1\%), これらの機能を使用せず通話機能の みを使用しているユーザを通話ユーザ（3 名， $8.1 \%$ ）とする.

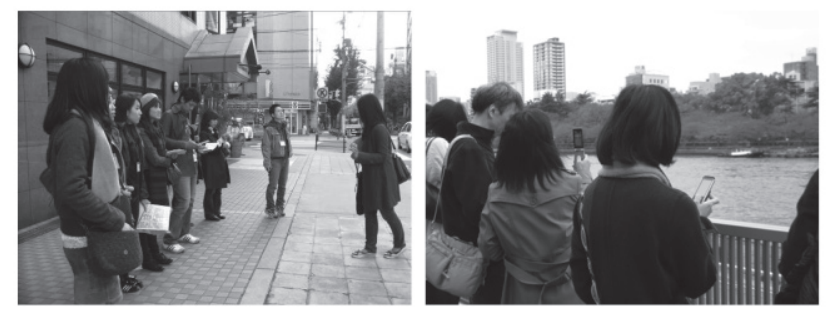

図 4 実験風景

\section{2 実験結果・考察}

(1) 旅行者発信情報の有効性

全 5 回の実証実験において, 収集した全てのデータ数は 368 であ った，その内，画像情報・位置情報・評価情報が全て存在するデー
タを有効データとした．それ以外のデータは無効データとした．結 果, 有効データ数は $275(74.7 \%)$ であり, 無効データ数は 93 (25.3\%) であった。

（2）位置情報の誤差検証

GPS により取得される位置情報の誤差について検証する．検証方 法は, 各有効データの位置情報と, 実際に撮影したと判断される地 点との位置情報との誤差をヒュベニの距離算出式 (1)により算出し た.

$$
D=\sqrt{(M \times d P)^{2}+(N \times \cos P \times d R)^{2}}
$$

$\mathrm{D}[\mathrm{m}]: 2$ 点間の距離, $\mathrm{P}[\mathrm{rad}]: 2$ 点の平均緯度, $\mathrm{dP}[\mathrm{rad}]: 2$ 点 の緯度差, $\mathrm{dR}[\mathrm{rad}]: 2$ 点の経度差, $\mathrm{M}[\mathrm{m}]$ ：子午線曲率半径 ${ }^{21)}$, $\mathrm{N}[\mathrm{m}]$ ：卯西線曲率半径 ${ }^{21)}$

一般に，携帯電話の GPS 精度は $10 \mathrm{~m}$ 前後といわれるが，屋外で 取得された位置情報のみを対象として分析した結果，本システムの 位置情報は, 平均誤差が $34.4 \mathrm{~m}$ となり, 誤差 $10 \mathrm{~m}$ 以上の割合が $78.8 \%$ と大きい結果となった。この要因を以下に考察する.

1. GPS により位置情報を取得する際には初期動作時間（30 秒〜 1 分）を要する. 本実験は, 団体での観光ツアーであり, 被験者 が周囲の動きに合わせながら位置座標の取得を行う必要があっ た.よって, 実際の撮影位置と GPS の取得位置にずれが生じた.

2. 建物, 樹木，金属などの遮蔽物が存在する環境では GPS を用い た位置推定を行うことは困難である ${ }^{22)}$. 今回の実験は，高層の ビルやマンション等の遮蔽物が立ち並ぶ高層地域での実験が計 4 回を占めていた. このため, 取得した位置座標の誤差が大きく なった.

考察 2 に関して検証するため, 高層のビルやマンションが立ち並 ぶ地域（以下，高層地域）と低層の建物や住宅が立ち並ぶ地域（以 下，低層地域）での位置情報の誤差を分析した。 サンプル数は高層 地域で 141, 低層地域で 62 であった。この結果，以下の 2 点が検証 結果として得られた(図 5).

高層地域で位置情報を取得した場合, 最小誤差 $1.5 \mathrm{~m}$, 最大誤差 は $193.8 \mathrm{~m}$ であり, 平均 $40.4 \mathrm{~m}$, 標準偏差 $31.5 \mathrm{~m}$ であった. また, 誤差 30m〜 40m 以内のサンプル数が $29(21.3 \%)$ と最も多く, 次いで誤差 $20 \mathrm{~m} \sim 30 \mathrm{~m}$ 以内が $22 （ 16.2 \%$ ）であった．誤差 $0 \mathrm{~m} \sim$ $40 \mathrm{~m}$ 以内のサンプル数は合計 87 で, 全体の $61.7 \%$ 占めた. 低層地域で位置情報を取得した場合, 最小誤差 $1.4 \mathrm{~m}$, 最大誤差 $105.5 \mathrm{~m}$ であり，平均 $18.2 \mathrm{~m}$ ，標準偏差 $19.9 \mathrm{~m}$ であった。また， 誤差 $0 \mathrm{~m} \sim 10 \mathrm{~m}$ 以内のサンプル数が $26(41.9 \%)$ と最も多く, 次 いで誤差 $10 \mathrm{~m} \sim 20 \mathrm{~m}$ 以内が $18(29.0 \%)$ であった. 誤差 $0 \mathrm{~m} \sim 30 \mathrm{~m}$ のサンプル数は合計 54 で, 全体の $87.1 \%$ 占めた.

以上より, 高層地域と低層地域とを比較すると, 高層地域のほう が誤差の平均值および標準偏差ともに大きい結果となり，また，高 層地域と低層地域との GPS による位置情報誤差の分布に違いが確 認できた。よって，収集システムを利用する場合は，対象地域によ り位置情報の誤差を考慮する必要がある。

（3）提案手法と従来型手法との比較

提案手法の有用性を検証するため, 有効データと, 従来型手法 (紙 の地図への評価コメントの記入）との比較分析を行った，得られた 


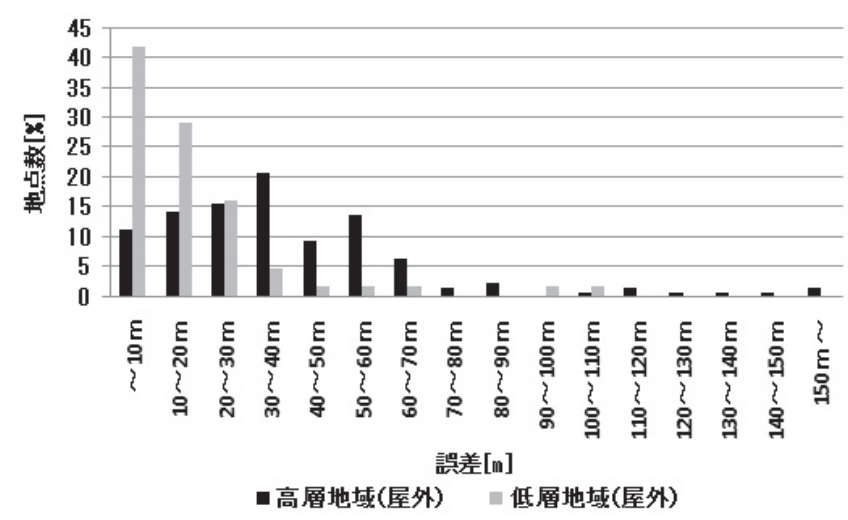

図 5 高層地域と低層地域の誤差分布比較

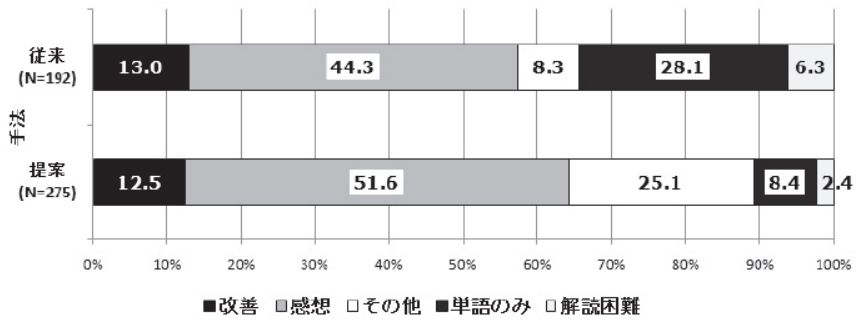

図 6 提案手法と従来型手法のコメント内容の比較

サンプル数は, 提案手法が 275 , 従来型手法が 192 であった。 分析 方法は, 各データに含まれる評価に関するコメントを, 文で記述さ れた「改善」,「感想」, 「その他」, および, 文で記述されてい ない「単語のみ」, そして「解読困難」の 5 種類に分類した。「解 読困難」とは, 文字の入力間違いや被験者が記述した文字を筆者が 読み取ることできなかったコメント，または文字を読み取ることが できた場合でも，筆者が意味を理解できなかったコメントを指す. 算出結果を図 6 に示す.

分析の結果, 提案手法では, 「改善」,「感想」,「その他」の文によ るコメント数が全体に占める割合 (89.2\%) が, 従来手法 (65.6\%) より 1.4 倍に増加した. 特に, 提案手法では, 「その他」が $25.1 \%$ で あるのに対し, 従来型手法では $8.3 \%$ と大きな差が見られた.一方, 従来型手法では「単語の夕」, 「解読困難」なデータが $34.4 \%$ と, 提 案手法の同データ (10.7\%) と比較して 3 倍以上となった。

以上より, 提案手法は従来型手法と比べて, 印象に残った数多く の旅行者発信情報を的確に収集できる点で一定の効果があると考え られる。

\section{(4) ユーザビリティ評価}

収集システムに対するユーザビリティ評価として,「システムの操 作性」,「画面・文字の大きさ」, 「GPS 取得時間満足度 (GPS 取得時 間は気にならなかったか) 」,「撮影満足度（十分に撮影できたか)」,

「記憶想起満足度 (地図記入と比較して思い出せたか)」,「実際に使 いたいか」について，5段階得点化（システム評価上位のものから 順に, 大変良い (満足, 大変思う） 5 点, 良い（まあ満足, 思う） 4 点, 普通 (どちらでもない) 3 点, 悪い（少し不満, 思わない） 2 点, 大変悪い（不満足, 全く思わない） 1 点）し, 加重平均手法に より各年代別および各ユーザ別の平均得点を算出した. さらに, ユ ーザビリティ特性の年齢別または各ユーザ別の平均值と全体平均值 の平均值差を計算し $\mathrm{t}$ 検定を行った. その結果を表 1 , 表 2 に示寸.
表 1 年齢別平均值差と $\mathrm{t}$ 検定の結果

\begin{tabular}{ccccccc}
\hline & $\begin{array}{c}\text { システム } \\
\text { の操作性 }\end{array}$ & $\begin{array}{c}\text { 字の大面・文 } \\
\text { さ }\end{array}$ & $\begin{array}{c}\text { GPS 取得 } \\
\text { 時間 }\end{array}$ & $\begin{array}{c}\text { 撮影満足 } \\
\text { 度 }\end{array}$ & $\begin{array}{c}\text { 記憶想起 } \\
\text { 満足度 }\end{array}$ & $\begin{array}{c}\text { 実際に使 } \\
\text { いたいか }\end{array}$ \\
\hline $\begin{array}{c}20 \text { 代 }(\mathrm{N}=19)- \\
\text { 全体 }\end{array}$ & -0.088 & 0.182 & -0.219 & -0.013 & 0.078 & 0.097 \\
\hline $\begin{array}{c}30 \text { 代 }(\mathrm{N}=7)- \\
\text { 全体 }\end{array}$ & -0.208 & -0.081 & -0.467 & 0.085 & -0.027 & -0.467 \\
\hline $\begin{array}{c}40 \text { 代 }(\mathrm{N}=8)- \\
\text { 全体 }\end{array}$ & 0.399 & -0.331 & 0.426 & 0.014 & -0.277 & 0.051 \\
\hline 50 代 $(\mathrm{N}=3)-$ \\
\begin{tabular}{c} 
全体 \\
\hline $\begin{array}{c}\text { 全体平均值 } \\
(\mathrm{N}=37)\end{array}$
\end{tabular} & -0.018 & -0.081 & $1.342 *$ & -0.153 & 0.306 & 0.342 \\
\hline & 3.351 & 4.081 & 2.324 & 3.486 & 4.027 & 3.324 \\
\hline
\end{tabular}

表 2 ユーザ別平均值差と $\mathrm{t}$ 検定の結果

システム 画面・文 GPS 取得 撮影満足 記憶想起 実際に使 の操作性字の大き時間度満足度 いたいか

\begin{tabular}{ccccccc}
\hline $\begin{array}{c}\text { パワーユーザ } \\
(\mathrm{N}=14) \text { - }\end{array}$ & 0.077 & $0.419^{*}$ & -0.110 & 0.228 & 0.116 & 0.033 \\
\hline $\begin{array}{c}\text { メールユーザ } \\
(\mathrm{N}=20) \text { 一全体 }\end{array}$ & -0.051 & -0.231 & 0.026 & -0.236 & -0.077 & 0.026 \\
\hline $\begin{array}{c}\text { 通話ユーザ } \\
(\mathrm{N}=3) \text { 一全体 }\end{array}$ & -0.018 & -0.414 & 0.342 & $0.514^{* *}$ & -0.027 & -0.324 \\
\hline $\begin{array}{c}\text { 全体平均值 } \\
(\mathrm{N}=37)\end{array}$ & 3.351 & 4.081 & 2.324 & 3.486 & 4.027 & 3.324 \\
\hline & $* *$ : 有意差 $1 \%$ 水準 & $*$ : 有意差 5\%水準 & 無印 : 有意差なし
\end{tabular}

表 3 評価項目の相関係数

\begin{tabular}{|c|c|c|c|c|c|c|}
\hline & $\begin{array}{l}\text { システム } \\
\text { の操作性 }\end{array}$ & $\begin{array}{c}\text { 画面・文 } \\
\text { 字の大き } \\
\text { さ }\end{array}$ & $\begin{array}{c}\text { GPS 取得 } \\
\text { 時間 }\end{array}$ & $\begin{array}{c}\text { 撮影満足 } \\
\text { 度 }\end{array}$ & $\begin{array}{l}\text { 記憶想起 } \\
\text { 満足度 }\end{array}$ & $\begin{array}{l}\text { 実際に使 } \\
\text { いたいか }\end{array}$ \\
\hline $\begin{array}{l}\text { システムの操 } \\
\text { 作性 }\end{array}$ & 1.000 & & & & & \\
\hline $\begin{array}{l}\text { 画面・文字の } \\
\text { 大きさ }\end{array}$ & $0.415^{* * * *}$ & 1.000 & & & & \\
\hline GPS 取得時間 & $0.141^{* * *}$ & $0.001^{* * *}$ & 1.000 & & & \\
\hline 撮影満足度 & 0.326 & $0.125^{* *}$ & $0.302^{* * *}$ & 1.000 & & \\
\hline $\begin{array}{l}\text { 記憶想起 } \\
\text { 満足度 }\end{array}$ & $0.066^{* *}$ & 0.352 & $0.096^{* * *}$ & $0.266^{* *}$ & 1.000 & \\
\hline $\begin{array}{l}\text { 実際に使いた } \\
\text { いか }\end{array}$ & 0.281 & $0.182^{* *}$ & $0.236^{* * *}$ & 0.150 & $-0.046^{* *}$ & 1.000 \\
\hline
\end{tabular}

表 1 で, ユーザビリティ特性の年齢別平均值と全体平均值の平均値. 差を計算した結果, 全ての年代で, 操作性, 画面・文字の大きさ, 撮影満足度, 記憶想起満足度の項目で 3 点以上の高い評価が得られ た。一方, 3 点未満の評価は, GPS 取得時間満足度 (50 代), 実際 に使いたいか（30 代）の項目である。 また, 表 2 で, 全てのユーザ で, 全ての項目について，3 点以上の高い評価が得られた。特に, パワーユーザは他のユーザと比較して, 開発したシステムを高く評 価すると共に, GPS 取得時間の長さに対して低く評価している.

次に, $\mathrm{t}$ 検定の結果, 有意な差は表 1,2 の網掛け部分であること が分かった。これらの要因を以下に考察する.

・表 1 では, 50 代の GPS 取得時間満足度が高いといえる.この理 由として, 50 代の $2 / 3$ は通話ユーザであり, 携帯電話の操作に 慣れておらず, カメラやメールなどの複雑な操作と比較して, GPS 取得時間の長さは気にならなかったと考えられる.

・表 2 では, パワーユーザの画面・文字の大きさへの評価が高い といえる. 携帯電話の操作に慣れているパワーユーザにとって, 開発したシステムの画面・文字の大きさで充分に使用可能であ 
ると考えられる.

・ 表 2 では, 通話ユーザの撮影満足度が高いといえる. 通話ユー ザは 50 代が $2 / 3$ を占めており, カメラ機能などの操作に慣れて いないものの，本システムを難なく使用することができたと考 えられる.

表 3 に評価項目間の相関を示す。「記憶想起満足度」と「実際に使 いたいか」以外はすべて正の相関が見られた. 特に「システムの操 作性」と「画面・文字の大きさ」の相関は最も高い結果となった. また, 「GPS 取得時間満足度」と「撮影満足度」, および「GPS 取得 時間満足度」と「実際に使いたいか」を見ると, 弱い相関が見られ た。この結果より,「撮影満足度」と「実際に使いたいか」を向上さ せるには, 「GPS 取得時間満足度」の向上, つまり位置座標の取得 にかかる時間を短縮することが効果的であると考えられる.さらに, 「撮影満足度」と「記憶想起満足度」に弱い相関が見られた。つま り, 画像を十分に撮影できる環境であれば, 撮影満足度を上昇させ ることができ, 結果として記憶がより強く想起され, 旅行者ニーズ の厳密な収集につながることが期待できると考えられる.

以上より, 位置座標取得にかかる時間の短縮の重要性が再確認で きただけでなく, システム操作性と画面・文字の大きさに相関関係 が確認できた。

（5）観光情報の収集に取り組む際の課題

収集システムを用いて, 観光情報の収集に取り組む際の課題を, 実験ツアー後のアンケート調査（複数回答可）より考察する.

結果, 「団体旅行だと, 周囲に気遣う」と回答した被験者が 25 名 $(67.6 \%)$ で, 利用場面として, ある程度制限があると考えられ る. 次いで「操作性が悪い」と回答した被験者が 17 名 (45.9\%) で, 操作性の悪さが収集率の向上の障害となると考えられる.また,「パ ケット代金がかかる」という回答も 13 名（35.1\%）あった。また， 特筆すべき自由記述闌でのコメントとして,「アンケートを重視し てしまうとアンケート主体のツアーになってしまう気がする.ガイ ドの話が十分に聞けなくなってしまう印象を受けた。」とあった. 旅行者発信情報を継続的に投稿してもらうためには, システムをよ り意識することなく利用できる工夫が必要である.

\section{5. 共有システムの開発}

共有システムは, 管理サーバ内部に蓄積された旅行者発信情報を, わかりやすく提示し, 多様な関係者が場所や環境を問わずに, 簡単 な操作で閲覧・共有できることが可能である.

旅行者発信情報の体系的分類方法は 2 章で述べたが, 本システム は, 3.1(4)で示した認知度と評価に関する 5 段階の回答に対して, 以 下のように分類する.

(i) 確認：認知度 (4.少し知っている, 5.知っている) ○評価 (4. まあ鬼力的だ，5.魅力的だ）

(ii) 発見: 認知度 (1.知らない, 2.ほとんど知らない, 3.どちらでも ない） ○評価（4.まあ魅力的だ，5.魅力的だ）

(iii) 失望: 認知度 (4.少し知っている, 5.知っている) ○ 評価 (1. 魅力的でない，2.あまり魅力的でない，3.どちらでもない）

(iv) 嫌悪 : 認知度 (1.知らない, 2.ほとんど知らない, 3.どちらでも ない）？評価（1. 魅力的でない，2.あまり魅力的でない，3，ど ちらでもない)

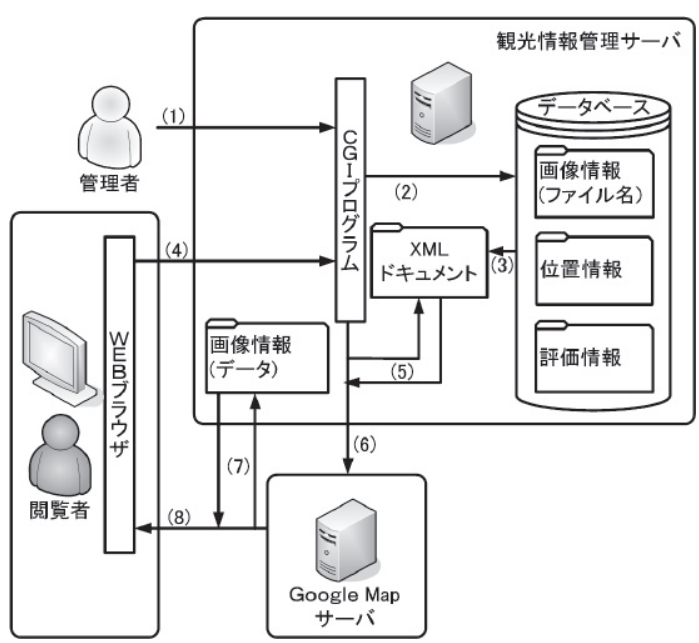

図 7 共有システムの構成図

\section{1 システムの構成}

共有システムは, Google Map サーバ, CGI プログラムおよびデー タベースを含む管理サーバによって構成されている，開発言語には PHP (Ver.5.2.10), HTML, JavaScript を利用し, データベースソフ トウェアには MySQL（Ver.5.1）を利用した. 構成図を図 7 に示す. また，共有システムで開発した機能を以下に示す。

（1） XML ドキュメントの作成機能

収集した旅行者発信情報（画像情報・位置情報・評価情報）を共 有システムで閲覧するため, まず，データベースに格納されている 位置情報・評価情報を, PHP の DOM 関数を用いて, 以下の手順で XML ドキュメントとして出力する.

（ア）旅行者発信情報の分類（i ）〜（iv）を結合のための選択条 件とし, 位置情報のデータテーブルと評価情報のデータテー ブルを, id を媒介として結合する.

(イ) DOMDocument::createElement 関数により, クラスの新しいイ ンスタンスを作成する.

(ウ) DOMNode::appendChild 関数により, 新しい子要素リストを作 成する.

(エ) DOMElement::setAttribute 関数を用いて, id ・ 経度・緯度・認 知度・評価・タイトル・コメント・ファイル名を, XML の要 素に設定する。

（オ）ドキュメントの保存先を指定し, 旅行者発信情報の分類（i ） 〜（iv）ごとに計 4 種類の XML ドキュメントを作成する.

（2）XML ドキュメントの切り替え・呼び出し機能 前項で作成した 4 種類の XML ドキュメントを Google Map サーバ に読み込み，閲覽者のブラウザに表示させる．さらに，観光情報の 分類（i ）〜（iv）を示すボタンを設けて, ボタンを切り替える度 に指定された XML ドキュメントを読み込むようにする.

（3）位置情報表示機能

管理サーバのデータベースに格納されている位置情報を， GMarker を用いて Google Map 上にマーカーを表示させる. GMarker は指定された位置に指定されたアイコンのマーカーを生成するコン ストラクタである. 留意点として，4.2(2)で述べたように GPS によ り取得された位置情報には誤差が含まれている, そのため, もし本 来の位置より大きくずれている場合には，作成した XML ドキュメ 
ントのデータを，書き直す必要がある。

（4）画像情報表示機能

管理サーバのデータベースに格納されている画像情報を, openInfoWindowHtml を用いて共有システム上に表示させる. openInfoWindowHtml は, マーカー上に指定された HTML コンテン ツを持つ情報ウィンドウを開くメソッドであり，HTML コンテンツ にXML ドキュメントの画像情報ファイル名を指定することで, 格 納されている画像を表示させる，画像情報に関しては，閲覧性向上 のため, 各画像を最大で $448 \times 336$ pixel とし, 天地の向きが不正確な 画像は回転させた。また，画像のブレが大きい画像は削除した。

（5）評価情報表示機能

評価コメントは，openInfoWindowHtml の HTML コンテンツにタ イトル・コメントを指定し, 表示させる. タイトル・コメントは日 本語で表示されるため, XML ドキュメントを作成する際, mb_convert_encoding 関数を用いて, 文字形式を utf-8 から euc-jp 一 変換する. 評価コメントが, 携帯端末専用文字使用による文字化け の場合, 評価情報のコメント内容が入力されていない場合, 「単語 のみ」や「解読困難」の場合には削除した。

また, mouseover 関数を用いることで, 地図上のマーカー上にマ ウスを移動させるだけで吹き出しが表示されるようにする.さらに， マーカー表示では画像や評価の内容が判別できないため, タイトル から閲覧できる機能を加えた。具体的には, id とタイトルを表示す るサイドバーを設け, タイトルをクリックすると, 対応するマーカ 一の吹き出しが開く.画像付き位置情報の表示画面例を図 8 に示寸.

\section{3 システム利用の流れ}

まず，管理者が管理サーバにアクセス寸ると（図 7 (1)), CGI プ ログラムが必要な情報（位置情報・評価情報）をデータベースより 取得する（図 7 （2））。このとき情報はXML ドキュメント形式で出 力され, サーバ内部の特定のフォルダに保存される (図 7（3））。管 理者は（1）〜（3）までを定期的に行う.この XML ドキュメント に追加, 修正がある場合は手動で入力する. 次に観光情報を閲覧す るため, 閲覽者が WEB ブラウザから管理サーバの URL にアクセス すると（図７（4）），CGI プログラムがサーバ内部に保存されている XML ドキュメントを取得し（図７（5)），Google Map サーバへ情報 を受け渡す (図 7 (6))。この後, Google Map サーバに XML ドキュ メント形式で提供された情報が WEB ブラウザに受け渡される(図 7 (8)) . この際, 同時に管理サーバ内部に格納されている画像情報を 取得し（図７（7)），投稿者の WEB ブラウザに初期画面が表示され る.

\section{6. 共有システムの検証}

開発した共有システムを検証するため, 実験を行った. 検証項目 は, 4 領域の分類内容, システムの提示方法, ユーザビリティ評価 である。

\section{1 実験方法}

共有システムのプロトタイプとして, 収集システムの実証実験で 収集した旅行者発信情報を用いた。評価方法として, 被験者はオン ライン上で共有システムを体験した後, ユーザビリティ特性に関す るWEB アンケートに回答した。また，観光やまちづくりに関連し た専門家（大阪市，近江八幡市）へヒアリング調查を実施した.

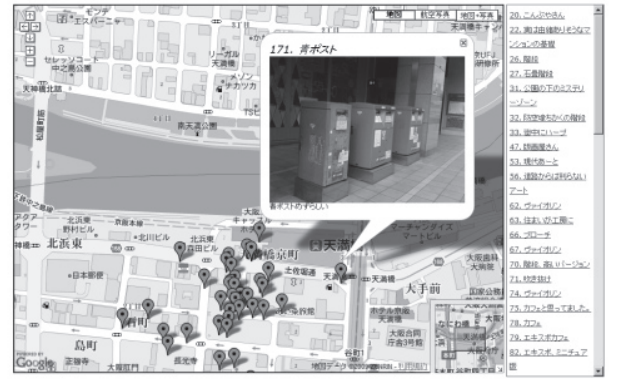

図 8 共有システム表示画面例

WEB アンケート調查は, 収集システムの実証実験の際の被験者, および大阪市・近江八幡市でまちづくり活動に参画している方々を 対象とした。調查実施期間は，平成 22 年 1 月 12 日〜 17 日の 6 日間 とした。なお，オンライン上で被験者が体験する共有システムは, 主にシステム操作性やインターフェースの検証を目的とするため, 切り替えボタンは失望と嫌悪の観光情報をまとめた 3 種類の状態で 実施した. 寸なわち，3 種類の観光情報（（ｉ）確認，（ii）発見， （iii）失望と嫌悪）とした。WEBアンケート調査の手順として, 被 験者は，作成した共有システムをインターネットで閲覧し，切り替 えボタン，吹き出しのコメント閲覽，サイドバークリックなどのシ ステム操作を体験した。共有システムを利用した後, インターネッ トによる評価フォームに回答した.

被験者は男性が 16 名（41\%），女性 23 名（59\%）の計 39 名であ った.また, 年齢構成は, 20 代が 10 名 (25.6\%), 30 代が 10 名 (25.6\%), 40 代が 15 名 (38.5\%), 50 代が 3 名 (7.7\%)，60 代以上が 1 名 (2.6\%) であり， 20 代〜 40 代の回答者が大半を占めた. また， 37 名（94.9\%） の被験者がほぼ毎日パソコンを使用していると回答した。一方, Google Map などの地図サービスの利用頻度について, ほぼ毎日利用 するとした被験者は 6 名 (15.4\%)，1 週間に数回が 14 名（35.9\%）, 1 力月に数回が 10 名 $(25.6 \%)$ ，ほとんど使わないが 9 名（23.1\%) と，バランスよく分布した.

\section{2 評価結果}

(1) 4 領域の分類内容

4.2(1) で示した有効データ（計 275）を，5章で示した分類方法に 基づき，（i ）確認，（ii）発見，（iii）失望，（iv）嫌悪の 4 つ に分類した，その結果，有効データのうち，発見領域が $154(56 \%)$ と最も多く, 次いで確認領域が 89 (32.4\%), 嫌悪領域が $24(8.7 \%)$, 失望領域が $8(2.9 \%)$ となった。各領域の画面例を図 9 に示す。 ま た，分類された旅行者発信情報の例を表 4 に示す.

収集システムによって得られる大量の旅行者発信情報は蓄積され, アクションプロセスで活用されることが大切である。ここで確認領 域が最も望ましい状態であるとすると, 発見領域は認知度を高める ことで確認領域へ，失望領域は改善することで確認領域へ，嫌悪領 域は改善し, 認知度を高めることで, 確認領域一近づけるようにす ることが求められる.ここで, 確認領域に蓄積される観光情報とは, 旅行者が事前に認知し, かつ評価している観光対象を実際に訪問し て確認, 納得する行為の現れである.したがって, アクションプロ セスでより重要と考えられる領域は，発見領域，失望領域，嫌悪領 域の 3 領域となる。本実験による 3 領域の総数は 186 (67.6\%) で あったため，6 割を超える有用な情報が得られたといえる. 

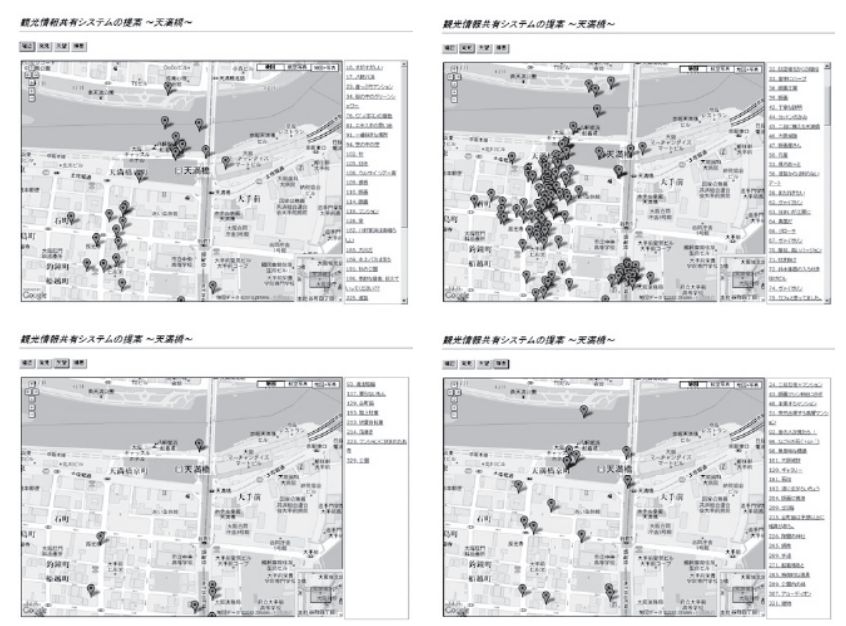

図 9 共有システムの例（大阪市）：(左上）確認領域，(右上）発見 領域, (左下) 失望領域, (右下) 嫌悪領域

（i ）確認, （ii ）発見, （iii）失望, （iv）嫌悪の四つに知識 化された観光情報の内容を考察する.

（i）確認領域に分類された旅行者発信情報（89）は, 対象地域 の観光資源として従来から有名である内容が多く含まれた。また, 被験者のうち地域精通者が投稿したと考えられる, その地域の人々 のみがよく知る資源も一部含まれていた.

（ii）発見領域に分類された旅行者発信情報（154）のうち，アク ションプロセスで改善できると考えられるものは, 知りたい, 行き たい，体験したいなどの希望や疑問を表す内容である。これらの内 容を含む旅行者発信情報は，16（9.6\%) であった。この他，「発見」 「感動」といった, 旅行者のリアルタイムの感情を表す内容の情報 も多く蓄積されていた. これらの情報は, 観光事業者が以降の観光 ルートで説明を増加させることで改善できる.また, 地域のプロモ ーション活動などに積極的に活用して旅行者一の認知度を高めてい くことで, 地域の新たな個性や魅力として, 価值付けが可能である.

（iii）失望領域に分類された旅行者発信情報（8）のうち，アクシ ヨンプロセスで改善できると考えられるものは, 違法駐輪や放置自 転車, 落書きなどであり, これらの内容を含む観光情報は 5 (62.5\%) と半数以上を占めた. 残りの情報は景観やその場の雾囲気を表して いるものであった。 これらの情報は, ヒアリング調查の結果, 観光 事業者が気づいていない情報も多かった.

（iv）嫌悪領域に分類された旅行者発信情報（24）のうち，アク ションプロセスで改善できると考えられるものは, 無意味な標識, 狭い道幅, 舗装の不整備, ゴミ箱などであり, これらの内容を含む 観光情報は $7(29.2 \%)$ であった。 これらの情報もまた, 観光事業 者が気づいていない情報も多かった。この他, 景観に不調和な高層 マンションなど, 存在は残念だが仕方ないという情報も多く含まれ ていた.

(2) 提示方法に対する専門家の評価

旅行者発信情報の提示方法に対する専門家へのヒアリング調査を 実施した（表 5) 。結果, 観光事業者が評価する観光資源と旅行者 の評価の差異を確認でき, また旅行者の思いがけない発見を知るこ とができるなど, 観光事業者が各種観光に係る計画や目標の見直し を行う観光マネジメントを支援するシステムとして一定の効果があ
表 4 分類された旅行者発信情報の例

（上：確認領域, 中上：発見領域, 中下：失望領域, 下：嫌悪領域）

\begin{tabular}{|c|c|c|c|c|}
\hline id 番号 & 27 & 33 & 77 & 315 \\
\hline タイトル & 町屋の佇まい & 新町通り & 白雲館 & 都住創 \\
\hline \multicolumn{5}{|l|}{ 画像 } \\
\hline コメント & $\begin{array}{l}\text { 生活景が溢れ } \\
\text { 出す } \\
\end{array}$ & $\begin{array}{l}\text { 新町通りは旧 } \\
\text { 八幡の顔 } \\
\end{array}$ & 町のシンボル. & $\begin{array}{l}\text { 一度中も見学 } \\
\text { してみたい. }\end{array}$ \\
\hline id 番号 & 19 & 61 & 270 & 278 \\
\hline タイトル & 屋上庭園 & 素敵な模様 & 八軒家浜の石 & 散歩 \\
\hline 画像 & & all & & \\
\hline コメント & $\begin{array}{l}\text { 無料で空中庭 } \\
\text { 園なんて知ら } \\
\text { ずびっくり. }\end{array}$ & 桜の木の根元 & $\begin{array}{l}\text { 古くからある } \\
\text { ものだったん } \\
\text { ですね. }\end{array}$ & $\begin{array}{l}\text { 時代が感じら } \\
\text { れまた紅葉が } \\
\text { きれいでした } \\
\end{array}$ \\
\hline id 番号 & 9 & 93 & 213 & 214 \\
\hline タイトル & 町屋 & 違法駐輪 & 放置自転車 & 落書き \\
\hline \multicolumn{5}{|l|}{ 画像 } \\
\hline コメント & 寂しい雰囲気 & $\begin{array}{l}\text { 折角の散歩コ } \\
\text { ースも台なし. }\end{array}$ & $\begin{array}{l}\text { 禁止表示があ } \\
\text { るのに停める } \\
\text { マナーのなさ } \\
\end{array}$ & 落書きが残念. \\
\hline id 番号 & 92 & 98 & 209 & 265 \\
\hline タイトル & 昔の人が見た & 無意味な標識 & ゴミ箱 & 銅像 \\
\hline \multicolumn{5}{|l|}{ 画像 } \\
\hline コメント & $\begin{array}{l}\text { 何か寂しいこ } \\
\text { こでせんでも } \\
\text { なー? }\end{array}$ & $\begin{array}{l}\text { 道の形状上, 多 } \\
\text { 分必要ないと } \\
\text { 思うのですが. }\end{array}$ & $\begin{array}{l}\text { 道沿いにゴミ } \\
\text { 箱があり, 景観 } \\
\text { が悪い. } \\
\end{array}$ & $\begin{array}{l}\text { 説明を聞くま } \\
\text { で目につかな } \\
\text { いのが残念. } \\
\end{array}$ \\
\hline
\end{tabular}

ると考えられる。一方で重要なスポットの提示方法や旅行者発信情 報の分類方法に, より詳細な検討が必要であると考察できる.

(3) ユーザビリティ評価

共有システムのユーザビリティ評価を行うためWEB アンケート を用いて, システム全般に関する「システムの操作性」,「文字の見 や寸さ」,「マーカー切り替え機能」,「インターフェースデザイン」 「実際に使いたいか」の 5 つの設問および，収集した旅行者発信情 報に対する評価「画像ぶれ」,「画像大きさのばらつき」,「マーカー 位置のずれ」,「コメント内容の理解」という 4 つの設問に対して, 5 段階得点化し, 加重平均法により平均值を算出した。 5 段階得点は 評価上位のものから順に, 大变良い（全く気にならない） 5 点, 良 い（気にならない）4 点, 普通（どちらでもない） 3 点, 悪い（気に なる） 2 点, 大変悪い（大変気になる） 1 点）として算出した。さら に, 被験者の評価対象地に対する理解や興味の度合いによりシステ ム評価に違いが生じることが考えられるため, 被験者の対象地への 訪問回数別平均值を計算した. その結果を表 6 に示す.

結果, 収集した旅行者発信情報に関する画像ぶれ，画像大きさの 
表 5 共有システムに対する専門家の意見と要望 内部での企画の評価に役に立つ。

人の目を通じて，お客様の声を聞けるメリットがある.

観光客を受け入れる側の想定の箇所と観光客の撮影した箇所や感想にズ レはなかったがその確認ができて上い。

見落とすようなところを感じることができ，また気づくことができる.

意普段, 光が当たらないものの発見になる。

見同じものを見ていてもこういう切り口で見ていたのかという発見がある. 観光情報が自分の感想と比較できるのはとても面白い。

写真があることで文章だけでは読み取れないような内容も伝わって良い. 「感激」「新発見」など，観光客を受け入れる側が意図していたものと違 ったコメントが含まれる場合, それらを吸い上げて提示してくれるような 機能があれば良い。

「交通量が多い」「違法駐輪が多い」など危険な場所が提示されると良い. コンビニ，トイレなどの用途の箇所がクリックごとに提示されると良い. 要動いているもの（車, 自転車, 人など）と静かなもの（建物, 植栽など）

望による分類が提示されると良い.

訪問スポットごとに観光客のデータが蓄えられ, それが各スポットの顧客 データとして利用できるようなスキームがあれば, 地域側にもメリットが あり，便利である。

ばらつき, マーカー位置のずれ，コメント内容の理解について，全 ての被験者により 3 点以上の高い評価が得られた。 また, システム 全般に関するシステム操作性, 文字見やすさ, マーカー切り替え機 能, インターフェースデザイン，実際に使いたいかにおいても 2.7 点以上と, ある程度高い評価が得られたと考えられる，特に訪問回 数 10 回以上の被験者により, 全評価項目に対して 3 点以上と高い評 価が得られた。したがって, システムのユーザビリティについて, 概初高い評価が得られたと考えられる。

次に, 結果から読み取ることのできる特徴的な傾向と考察を示す。 訪問回数が「9 回以下」の被験者は, システム全般に関する評価 のうち「文字の見やすさ」,「マーカー切り替え機能」,「インタ ーフェースデザイン」において,「10 回以上」の被験者と比較し て低い值を示した。この理由として, 訪問回数が少ない被験者 は，対象地域のことをあまり知らないため，観光情報の内容よ り, システムの機能に対してより仔細に評価したと考えられる. 訪問回数が「10 回以上」の被験者は, 収集した観光情報に関す る評価のうち「画像ぶれ」,「マーカー位置のずれ」において， 訪問回数が「9回以下」の被験者と比較して，低い值を示した． この理由として, 訪問回数が多い被験者は, 自身がよく知って いる対象地域に対する旅行者発信情報に強い関心を持ったため, システム全般よりも情報自体の内容に対してより仔細に評価し たと考えられる.

以上より, 現地訪問回数の多少により, システムに対する着眼点 が異なることを考慮する必要があると考えられる。

評価項目間の相関を表 7 に示す。.まず, 「画像ぶれ」は, 他の全 ての評価項目と正の相関が見られた。特に，「画像ぶれ」と「文字 の見やすさ」および「画像大きさのばらつき」には, 中程度の相関 が見られた。このことより，「画像ぶれ」に関する評価が上昇寸れ ば，「文字の見やすさ」，「画像大きさのばらつき」などの項目だ けでなく，「実際に使いたいか」や「コメント内容の理解」にも効 果が現れると期待できる。また，「実際に使いたいか」と「文字の 見やすさ」には，弱い相関が見られた。このため，共有システムの 構築に際しては，「文字の見やすさ」も，「画像ぶれ」と同じく， 優先すべき改善課題であると考えられる.さらに，「コメント内容 の理解」と「インターフェースデザイン」には中程度の相関が，「コ メント内容の理解」と「文字の見や寸さ」および「コメント内容の 理解」と「マーカー切り替え機能」には弱い相関が見られた。この
表 6 訪問回数別平均值

\begin{tabular}{|c|c|c|c|c|c|}
\hline 訪問回数 & $\begin{array}{c}\text { システムの } \\
\text { 操作性 }\end{array}$ & $\begin{array}{c}\text { 文字の見や } \\
\text { すさ }\end{array}$ & $\begin{array}{c}\text { マーカー切 } \\
\text { 換機能 }\end{array}$ & $\begin{array}{l}\text { インターフェース } \\
\text { デザイン }\end{array}$ & $\begin{array}{c}\text { 実際に使い } \\
\text { たいか }\end{array}$ \\
\hline \multirow{2}{*}{ 0〜3 回 } & 3.000 & 2.813 & 2.938 & 2.938 & 3.688 \\
\hline & 0.400 & 0.563 & 0.596 & 0.596 & 0.496 \\
\hline \multirow{2}{*}{$4 \sim 9$ 回 } & 2.750 & 2.750 & 2.750 & 2.750 & 2.750 \\
\hline & 0.917 & 0.917 & 0.917 & 0.917 & 0.917 \\
\hline \multirow{2}{*}{10 回以上 } & 3.263 & 3.211 & 3.263 & 3.105 & 3.263 \\
\hline & 0.649 & 1.064 & 0.427 & 0.433 & 1.094 \\
\hline \multirow{2}{*}{ 全体 } & 3.103 & 3.000 & 3.077 & 3.077 & 3.385 \\
\hline & 0.568 & 0.842 & 0.547 & 0.547 & 0.874 \\
\hline 訪問回数 & 画像ぶれ & $\begin{array}{l}\text { 画像大きさ } \\
\text { のばらつき }\end{array}$ & $\begin{array}{l}\text { マーカー位 } \\
\text { 置のずれ }\end{array}$ & $\begin{array}{l}\text { コメント内 } \\
\text { 容の理解 }\end{array}$ & \\
\hline \multirow{2}{*}{$0 \sim 3$ 回 } & 4.063 & 3.250 & 3.688 & 3.750 & \\
\hline & 0.329 & 1.400 & 0.896 & 0.867 & \\
\hline \multirow{2}{*}{$4 \sim 9$ 回 } & 4.250 & 3.500 & 3.500 & 3.000 & \\
\hline & 0.250 & 1.000 & 1.000 & 0.667 & \\
\hline \multirow{2}{*}{10 回以上 } & 3.632 & 3.158 & 3.000 & 3.526 & \\
\hline & 1.023 & 1.585 & 0.889 & 0.485 & \\
\hline \multirow{2}{*}{ 全体 } & 3.872 & 3.231 & 3.333 & 3.564 & \\
\hline & 0.694 & 1.393 & 0.965 & 0.673 & \\
\hline
\end{tabular}

表 7 評価項目の相関係数

\begin{tabular}{|c|c|c|c|c|c|}
\hline & $\begin{array}{c}\begin{array}{c}\text { システムの } \\
\text { 操作性 }\end{array} \\
\end{array}$ & $\begin{array}{c}\begin{array}{c}\text { 文字の見や } \\
\text { すさ }\end{array} \\
\end{array}$ & $\begin{array}{c}\text { マーカー切 } \\
\text { 換機能 }\end{array}$ & 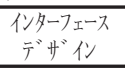 & $\begin{array}{c}\text { 実際に使い } \\
\text { たいか } \\
\end{array}$ \\
\hline $\begin{array}{c}\text { システムの } \\
\text { 操作性 }\end{array}$ & 1.000 & & & & \\
\hline $\begin{array}{c}\text { 文字の見や } \\
\text { すさ }\end{array}$ & 0.571 & 1.000 & & & \\
\hline $\begin{array}{c}\text { マーカー切 } \\
\text { 換機能 }\end{array}$ & 0.505 & 0.310 & 1.000 & & \\
\hline 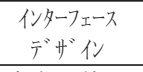 & 0.458 & 0.233 & 0.519 & 1.000 & \\
\hline $\begin{array}{c}\text { 実際に使い } \\
\text { たいか }\end{array}$ & 0.465 & $0.276 \triangle$ & 0.527 & 0.413 & 1.000 \\
\hline $\begin{array}{l}\text { 画像 } \\
\text { ぶれ } \\
\end{array}$ & $0.009 * * *$ & $0.434^{* * *}$ & $0.142^{* * *}$ & $0.052^{* * * *}$ & $0.382^{* *}$ \\
\hline $\begin{array}{l}\text { 画像大きさ } \\
\text { のばらつき }\end{array}$ & -0.234 & 0.146 & -0.081 & -0.172 & 0.108 \\
\hline $\begin{array}{c}\text { マーカー } \\
\text { 位置のずれ }\end{array}$ & -0.118 & 0.088 & -0.036 & -0.109 & -0.143 \\
\hline $\begin{array}{l}\text { コメント内 } \\
\text { 容の理解 }\end{array}$ & $-0.053^{*}$ & $0.245^{* *}$ & $0.187^{* *}$ & $0.404^{* *}$ & 0.087 \\
\hline 訪問回数 & 画像ぶれ & $\begin{array}{c}\text { 画像大き } \\
\text { さのばら } \\
\text { つき } \\
\end{array}$ & $\begin{array}{c}\text { マーカー } \\
\text { 位置のず } \\
\text { れ }\end{array}$ & $\begin{array}{c}\text { コメント } \\
\text { 内容の理 } \\
\text { 解 }\end{array}$ & \\
\hline $\begin{array}{l}\text { 画像 } \\
\text { ぶれ } \\
\end{array}$ & 1.000 & & & & \\
\hline $\begin{array}{l}\text { 画像大きさ } \\
\text { のばらつき }\end{array}$ & $0.547^{* *}$ & 1.000 & & & \\
\hline $\begin{array}{l}\text { マーカー位 } \\
\text { 置のずれ }\end{array}$ & $0.293^{* *}$ & 0.250 & 1.000 & & \\
\hline $\begin{array}{l}\text { コメント内 } \\
\text { 容の理解 } \\
\end{array}$ & $0.410^{*}$ & 0.297 & 0.283 & 1.000 & \\
\hline
\end{tabular}

ことより，「インターフェースデザイン」および「文字の見やすさ」 の向上が「コメント内容の理解」に影響することが明らかとなった.

\section{7. 結論と今後の課題}

\section{1 結論}

本研究では，我が国が観光立国を目指す上で，旅行者の感想や要 望を的確に収集し, 収集された大量の旅行者発信情報を共有可能な 観光マネジメント支援システムを構築し, 実験によりシステムの有 効性を検証した。本システムを用いることで，観光事業者をはじめ とする関係者は, 旅行者の発見や失望の内容を画像情報・位置情報 と共に知ることができる，収集される大量の旅行者発信情報は，ツ 
アー企画を再検討するアクションプロセスにおいて, 有用な基礎資 料となると考えられる. 以下に, 本システムを構成する収集システ ムと共有システムの特徵と効果を示す.

(1) 収集システムの特徵と効果

・収集システムは, GPS 携帯端末，MySQL・PHP など汎用性の高 い技術により構成される，ユーザビリティ評価では，操作性， 画面・文字の大きさ, 撮影満足度, 記憶想起満足度において, 全ての年代で 5 点満点中 3 点以上の高い評価が得られた。

・ 計 5 回の実証実験を通して, 全旅行者発信情報のうち 275 (74.7\%) の有効データを得ることに成功した.

・ 従来型手法と比較して, 文章によるコメント数が増加したこと や,「単語のみ」, 「解読困難」などのコメント数が 3 分の 1 以下に減少したことから, 印象に残った旅行者発信情報をリア ルタイムに収集できる。

・実証実験では, 高層地域で平均 $40.4 \mathrm{~m}$, 低層地域で平均 $18.2 \mathrm{~m}$ の位置情報の誤差が生じた。位置情報に含まれる誤差を対象地 域別に考慮する必要がある.

(2) 共有システムの特徵と効果

・ 共有システムは, Google Map・PHP・HTML・Ajax・XML・MySQL など汎用性の高い技術により構成される。ユーザビリティ評価 では，概ね高い評価が得られた。

・実験により得られた旅行者発信情報を四密分析により分類した 結果, アクションプロセスに重要な 3 領域である発見領域, 失 望領域，嫌悪領域の総数は $186(67.6 \%)$ であり，6 割を超える 有用な情報が得られた。 アクションプロセスにおいて改善可能 と考えられる情報は，発見領域が $16(9.6 \%)$ ，失望領域が 5 (62.5\%)，嫌悪領域が 7 （29.2\%）であった.

- 訪問回数が少ない回答者は操作性等のシステムについて全体平 均より低い評価を示し, 訪問回数が多い回答者は観光情報の内 容について全体平均より低い評価を示した。これは, 訪問回数 の差によって, システムを利用する際の着眼点に違いがあるこ とを示唆している.

\section{2 今後の課題}

本研究で構築したシステムの内, 収集システムの課題として, 位 置座標の取得にかかる初期動作時間を短縮する必要があること，シ ステムの操作性の改善を図る必要があること,が挙げられる.また, 共有システムの課題として, 大量に蓄積された旅行者発信情報に対 する綿密で効率的な提示方法, 画像のぶれや文字の見やすさに対す る改良, 3 次元地図の利用など提示方法に関する機能の開発が必要 であると考えられる.

最後に, 本研究の実証実験では, 60 代以上の高齢者や視聴覚障害 者などを被験者とすることができなかった。いわゆる情報弱者に対 する検証が必要であると考えられる. また, 収集システムの検証実 験は，3 日間のみの実施であったが，継続的に運用した場合，マー カーの数は際限なく増加すると考えられる. そのため, マーカーの 表示方法をより詳細に検討する必要がある。

\section{謝辞}

本研究の検証実験は, 独立行政法人科学技術振興機構「平成 21 年度地域の科学舎推進事業地域活動支援 (草の根型)」の援助の下に
行われた。ここに記して謝意を表す。

\section{参考文献}

1）国土交通省：観光立国推進基本計画，2007

2）萬代祐介:まちめぐりナビプロジェクトについて, JACIC 情報 第 94 号, 2009

3）総務省：平成 21 年度情報通信利用動向調查， 2010

4）目黒浩一郎，鈴木啓史：GPS 携帯電話を活用した新たなソリューション の開発，三菱総合研究所所報 (48), pp. 72-91， 2007

5）国土交通省：自律移動支援プロジェクト， http://www. jiritsu-project.jp/,（参照 2011-01-17）

6）安原達: ユビキタス情報社会における次世代河川管理のあり方について, 日本建築学会総合論文誌, 第 8 号, pp. 73-76, 2010

7）嶋田善多，矢吹信喜，坂田智己：土木設備の維持管理体系における巡視 点検と IC タグの活用, 土木学会論文集, No. 777/VI-65, pp. 161-173, 2004

8) Koshak Nabeel A. and Abdullah Fouda: Analyzing Pedestrian Movement in Mataf Using GPS and GIS to Support Space Redesign, Design \& Decision Support Systems in Architecture and Urban Planning, pp. 1-14. , 2008

9）長尾光悦，川村秀憲，山本雅人，大内東：GPS ログマイニングに基づく 観光行動情報の取得, 観光情報学会誌, 第 1 巻, 第 1 号, pp. 38-46, 2005

10）三澤勉，有村幹治，田村亨 : 携帯情報端末を用いた観光情報提供に関わ る周遊行動データの収集方法の提案とその基礎的分析, 都市計画学会論 文集，No. 38-3，pp. 449-504，2003

11）古谷知之: 携帯型位置情報端末を用いた観光行動動態の時空間データマ イニング 一箱根地域を事例として一, 日本都市計画学会論文集, No. 41-3, pp. 1-6, 2006

12）野村幸子，岸本達也：GPS・GIS を用いた鎌倉市における観光客の歩行行 動調査とアクティビティの分析, 日本建築学会総合論文誌, No. 1543, pp. $72-77,2006$

13) Todspol Tedrumpun and Walaiporn Nakapan: Site Measurement With Combination of Pocket PC and Global Positioning System for Preliminary Architectural Design Process, Proceedings of the 9th International Conference on Computer Aided Architectural Design Research in Asia, pp. 717-726, 2004

14）石内鉄平，米倉達広，小柳武和，桑原祐史：パークマネジメントにおけ る利用者体験情報共有システムの提案, 土木情報利用技術論文集, vol. 18 , pp. 101-108, 2009

15）遠藤広樹，登川幸生：移動体通信機器を用いた景観調査システムの構築 に関する研究, 日本建築学会・情報システム技術委員会, 第 32 回情報・ システム・技術シンポジウム, pp. 61-65, 2009

16) Bauke De Vries, Yuzhong Lin and Joran Jessurun: Sense-of-the-City, Design \& Decision Support Systems in Architecture and Urban Planning, pp. $1-10,2008$

17）上田紀之，中西泰人，真鍋隆太郎，本江正茂，松川昌平：時空間ポエマ 一+カキコまっぷ：GPS カメラケータイを用いた WebGIS の構築，電子情 報通信学会技術研究報告, pp. 71-76, 2003

18）加賀有津子, 宮川淳, 河口将弘, 呂显絃, 福田知弘：GPS カメラ付き携 帯電話を利用した地域景観評価システムの構築, 日本建築学会・情報シ ステム技術委員会, 第 28 回情報・システム・技術シンポジウム, pp. 55-60, 2005

19）竹林征三：自・他の双方コミュニケーション一風土工学・四空分析一, 土木学会誌, Vol.94, No. 12, 2009

20) Japan Electronics and Information Technology Industries Association: Exchangeable image file format for digital still cameras:Exif Version 2.2, 2002

21）国土地理院測地部：計算式, http://vldb. gsi.go. jp/sokuchi/ surveycalc/algorithm/, 参照 2011-01-17)

22）大森宣暁，室町泰徳，原田昇，太田勝敏：高精度情報機器を用いた交通 行動デー夕収集の可能性, 第 34 回日本都市計画学会学術研究論文集, pp. 169-174, 1999

23）吉川泰代，福田知弘，矢吹信喜：ICT を用いた観光情報マネジメントシ ステムの開発, 平成 22 年度日本建築学会近畿支部研究報告集, 第 50 号・ 計画系, pp. 641-644, 2010

（2010年 8 月24日原稿受理，2011年 1 月17日採用決定） 